\title{
SYARAT SAH KESEPAKATAN DALAM PERJANJIAN TRANSAKSI ELEKTRONIK PADA APLIKASI JUAL BELI ONLINE LAZADA
}

\author{
Oleh : \\ Arkiswan*, Debby Puspita Sari** \\ *Fakultas Hukum Universitas Gresik \\ Email : arkismanfhug@gmail.com \\ **Fakultas Hukum Universitas Gresik \\ Email : debbypuspita81@gmail.com
}

\begin{abstract}
ABSTRAK
Perkembangan teknologi dan informasi semakin mendorong munculnya berbagai kegiatankegiatan yang dilakukan masyarakat melalui internet. Salah satu kegiatan di dunia maya yaitu transaksi elektronik (electronic commerce). Dimana dalam transaksi elektronik penjual dan pembeli tidak bertemu atau bertatap muka secara langsung tetapi menggunakan media elektronik berupa komputer yang terhubung dalam suatu jaringan internet sebagai alat untuk berkomunikasi dan melakukan transaksi. Dalam penulisan ini, penulis mengangkat dua permasalahan. Permasalahan pertama adalah bagaimana sahnya perjanjian transaksi elektronik bila para pihak tidak pernah bertemu secara langsung untuk bersepakat. Permasalahan kedua adalah apa upaya hukum dari perjanjian transaksi elektronik jika salah satu pihak yang tidak pernah bertemu secara langsung untuk bersepakat ada yang tidak sepakat.
\end{abstract}

Kata kunci : Perjanjian, Transaksi, Elektronik, Sepakat.

\section{PENDAHULUAN}

\section{A. Latar Belakang}

Suatu kenyataan sosial

menunjukkan teknologi informasiberkembang jauh lebih pesat dan telah mengubah pola dan prilaku masyarakat, misalnya saja dalam transaksi bisnis dari pola konvensional dengan cara tatap muka atau kontrak offline, bergeser ke era kontrak elektronik melalui komputer dengan cara kontrak online. Era globalisasi telah membawa perubahan di berbagai bidang kehidupan, termasuk perkembangan teknologi informasi dan komunikasi yang memegang peranan penting dalam pembangunan.Teknologi informasi dan komunikasi telah mengubah perilaku masyarakat dan peradaban manusia secara global. Perkembangan teknologi informasi telahmenyebabkan dunia menjadi tanpa batas (borderless) dan menyebabkan perubahan sosial secara signifikan berlangsung demikian cepat. Pengakuan kontrak elektronik sebagai suatu bentuk perjanjian dalam Kitab Undang-Undang Hukum Perdata (K.U.H. Perdata) Indonesia masih merupakan permasalahan yang pelik. Pasal 1313 K.U.H. Perdata mengenai definisi perjanjian memang tidak menentukan bahwa suatu perjanjian harus dibuat secara tertulis. Pasal 1313 K.U.H.
Perdata hanya menyebutkan bahwa perjanjian adalah suatu perbuatan dengan mana satu orang atau lebih mengikatkan dirinya terhadap satu orang lain atau lebih. Jika mengacu pada definisi ini maka suatu kontrak elektronik dapat dianggap sebagai suatu bentuk perjanjian yang memenuhi ketentuan Pasal 1313 K.U.H. Perdata tersebut. Namun pada prakteknya suatu perjanjian biasanya ditafsirkan sebagai perjanjian yang dituangkan dalam bentuk tertulis dan bila perlu dituangkan dalam bentuk akta notaris atau dalam bentuk elektronik, salah satunya berupa surat elektronik (e-mail).

Kontrak melalui surat elektronik (e-mail) adalah salah satu kontrakelektronik yang sangat populer karena penggunaan email saat ini sangat banyak dan mendunia, dengan biayayang sangat murah dan waktu yang efisien. Untuk memperoleh alamat surat elektronik (e-mail), dapat dilakukan dengan cara mendaftarkan diri sebagai subscriber pada server atau ISP (Internet Service Provider) tertentu. "Kontrak berupa email dapat berupa penawaran yang dikirim kepada seseorang atau banyak orang yang tergabung dalam sebuah mailinglist (daftar kirim), serta 
penerimaan dan pemberitahuan penerimaan yang seluruhnya dikirim melalui surat elektronik (e-mail)." Perjanjian merupakan peristilahan terjemahan dari kata overeenkomst (Belanda) atau contract (Inggris)." ${ }^{2}$ Kontrak pada dasarnya dibuat berdasarkan kebebasan berkontrak. Prinsip-prinsip kebebasan untuk membuat kontrak atau peranjian, dalam hukum perdata pada dasarnya setiap orang diberi kebebasan untuk membuat perjanjian baik dari segi bentuk maupun muatan. Kebebasan berkontrak dapat disimpulkan dari ketentuan Pasal1338 ayat (1) K.U.H. Perdata yang menyebutkan, bahwa semua perjanjian yang dibuat secara sah berlaku sebagai Undang-Undang bagi mereka yang membuatnya.

"Asas kebebasan berkontrakadalah suatu asas yang memberikan kebebasan kepada para pihak untuk:

(1) membuat atau tidak membuat perjanjian; (2) mengadakan perjanjian dengan siapa pun; (3) menentukan isi perjanjian, pelaksanaan, dan persyaratannya; (4) menentukan bentuknya perjanjian, yaitu tertulis atau lisan."

(2) Suatu kontrak atau perjanjian harus memenuhi syarat sahnya perjanjian, yaitu kata sepakat, kecakapan, hal tertentu dan suatu sebab yang halal, sebagaimana ditentukan dalam Pasal 1320 K.U.H. Perdata. "Dengan dipenuhinya empat syarat sahnya perjanjian tersebut, maka suatu perjanjian menjadi sah dan mengikat secara hukum bagi para pihak yang membuatnya." 4

(3) Jika melihat salah satu syarat sahnya perjanjian dalam Pasal 1320 K.U.H. Perdata, yaitu adanyakecakapan maka akan menjadi permasalahan jika pihak dalam jual beli melalui internet adalah anak di bawah umur, hal ini mungkin terjadi karena untuk mencari identitas yang benar melalui media internet tidak mudah, juga apabila melihat unsur yang lain seperti terjadinya kesepakatan menjadi pertimbangan untuk menentukan relevansi penerapan asas-asas hukum yang selama ini berlaku dalam duniainternet.

(4) Dalam kesepakatan jual-beli jarang sekali diperhatikan mengenai kesepakatan di kedua belah pihak antara si pembeli dan penjual terlebih dalam transaksi jual-beli online, dikarenakan kedua belah pihak tidakbertemu dan bertatap muka secara langsung, sehingga bisa jadi diantara dua belah pihak tersebut pada kenyataannya tidak menyepakati perjanjian jual-beli tersebut Kenyataannya pada praktek,banyak kalangan yang belum mengetahui mekanisme untuk membuat perjanjian dibawah tangan secara elektronik. Tidak mengetahui apa landasan hukumnya serta apa yang menjadi hak dan kewajibannya. Sehingga menimbulkan kesan bahwakontrak melalui surat elektronik (email) tidak friendly use dan susahuntuk diaplikasikan. Padahal seperti yang diketahui, masyarakat dewasa ini sangat erat kaitannya dengan dunia informasi elektronik.

\section{METODE PENELITIAN}

Metode penelitian ini merupakan cara yang digunakan untuk mendapatkan data serta memperoleh jawaban yang akurat atas rumusan masalah diatas dengan mencari dan mengelola data dalam suatupenelitian. "Jenis penelitian ini adalah penelitian hukum normatif, penelitian hukum untuk menemukan aturan hukum, prinsip-prinsip hukummaupun doktrin-doktrin hukum Peneliti akan mendapatkan informasi dari berbagai aspek mengenai isu yang sedang dicoba untuk dicari jawaban." Hasil dari penelitian ini memberikan preskripsi mengenai rumusan masalah yang diajukan, penelitian normatif hanya meneliti norma hukum, tanpa melihat praktek hukum di lapangan (law in action). Terkait dengan pengkajian sahnya perikatan transaksi elektronik berdasarkan Pasal 1320 ayat (1) K.U.H Perdata tentang kata sepakat. Metode pendekatan merupakan salahsatu tahapan penelitian yang dimaksudkan untuk mengumpulkan data-data dalam berbagai aspekterkait sahnya perjanjian dalamtransaksi elektronik untuk mencari jawaban atas permasalahan yang telah dirumuskan dalam penelitian ini, tentang kata sepakat. Penulis menggunakan tiga metode pendekatan antara lain pendekatan konseptual (conceptual approach), pendekatan perundangundangan (statute approach), dan pendekatan Komparatif (comparative approach). 1). Pendekatan Konseptual (conceptual approach). Pendekatan yang beranjak dari pandanganpandangan dan doktrin-doktrin yang berkembang di dalam ilmu hukum. Dengan mempelajari pandangan- pandangan dan doktrin-doktrin didalam ilmu hukum, peneliti akan menemukan ide-ide yang melahirkan pengertian-pengertian hukum. Pendekatan konseptual dilakukan guna dijadikan sebagai acuan untuk membangun argumentasi hukum yang berkaitan dengan pokok permasalahan dalam penelitian ini. 2). Pendekatan perundangundangan (statute approach). Merupakan Pendekatan perundang-undangan dilakukan dengan menelaah semua undangundang dan regulasi yang bersangkut paut dengan isu karena yang akan diteliti adalah berbagai aturan hukum yang menjadi fokus sekaligus tema sentral suatu penelitian. Dilakukan dengan cara menelaah dan mengkaji semua peraturan perundang-undangan yang berkaitan dengan pokok permasalahan yang dirumuskan dalam penelitian ini. Pendekatan perundang-undangan ini digunakan 
untuk mendapatkan ketentuan- ketentuan hukum guna untuk mempelajari konsistensi dan kesesuaian antara undang-undang dan undang-undang lainnya,

Pendekatan Komparatif (comparative approach). merupakan Perbandingan hukum yang lazimnya dilakukan untuk membandingkan hukum suatu negara dengan hukum negara lain, bisa juga dengan membandingkan peraturan dengan peraturan setingkat dan/atau membandingan dengan peraturan diatas atau dibawahnya. Penelitian ini merupakan suatu studiatau kajian perbandingan mengenai konsepsi-konsepsi intelektual yangada di balik institusi atau lembaga hukum yang pokok dari satu atau beberapa sistem hukum nasional.

Pada penulisan skripsi ini, perbandingan yang dilakukan adalah terhadap Undang-Undang Nomor 11 Tahun 2008 tentang Informasi dan Transaksi Elektronik dengan Kitab Undang-Undang Hukum Perdataberkaitan dengan Pasal 1320 ayat (1).

\section{PEMBAHASAN}

\section{Pengaturan hukum terhadap transaksi} elektronikberdasarkan Pasal 1320 ayat (1) K.U.H. Perdata tentang kata sepakat

Kata sepakat di dalam perjanjian pada dasarnya adalah persesuaian kehendak antara para pihak yang melakukan suatu perjanjian. Seseorang dikatakan memberikanpersetujuannya dan kesepakatannya jika dia memang menghendaki apa yang disepakati. Hal ini sesuai dengan asas konsensualisme dalamsuatu perjanjian bahwa suatu kontrak yang telah dibuat maka telah sah dan mengikat secara penuh bagi para pihak yang membuatnya Perjanjian yang ada dalam transaksi e-commerce muncul karena adanya kesadaran dari para pihak untuk saling mengikatkan diri. Pihak pembeli menyetujui atau menyepakati klausul kontrak yang telah disepakati oleh penjual. Klausul kontrak ini biasanya telah disediakan dan pembeli tinggal menyetujuinya dengan cara mencontreng pada kotak yang disediakan atau menekan tombol accept sebagai tanda persetujuan.

1) Perjanjian dalam kontrak $e$ - commerce merupakan suatu perjanjian take it or leave it, sehingga jika pembeli setuju maka ia akanmenyetujui perjanjian tersebut, jika tidak maka pembeli tidak perlumelakukan persetujuan dan proses transaksi pun batal atau tidak terjadi. Perjanjian atau kontrak yang terjadi dalam e-commerce terjadi karena adanya kesepakatan, apabila dikaitkan dengan teori perjanjian yang diungkapkan oleh Munir Fuady dalam bukunya hukum kontrak dari sudut hukum bisnis, untuk menentukan kapan suatu kesepakatan terjadi dapat digunakan sebagai suatu patokan untuk menentukan keterikatan seseorang pada perjanjian tertutup sehingga perjanjian dianggap telah mulai berlaku, teori tersebut, yaitu: ${ }^{6}$ Teori Penawaran

2) Kesepakatan kehendak padaprinsipnya baru terjadi setelahadanya penawaran (offer) dari salah satu pihak yang kemudian diikuti dengan penerimaan tawaran (acceptance) oleh pihak lain dalam perjanjian tersebut, sehingga menurut teori inikesepakatan antar pihak terjadi pada saat penjual mengajukan penawaran dengan menyediakan daftar atau katalog barang (product table) yang disertai dengan deskripsi produk yang dijual kemudian customer yang memilih produk yang ditawarkan dengan mengklik kotak yang disediakan.

\section{Teori Pernyataan (Verklarings Theorie)}

Menurut teori pernyataan, apabilan ada kontroversi antara apa yang dikehendaki dengan apa yang dinyatakan, maka apa yang dinyatakan tersebutlah yang berlaku, karena masyarakat pada umumnya menghendaki bahwa apa yang dinyatakan dapat dipegang. Berdasarkan teori ini,apa yang dinyatakan oleh customer dengan cara mengisi order form maka itulah yang dianggap berlaku, bukan lagi apa yang dikehendakinya. Demikian juga dengan apa yang dinyatakanoleh penjual yang berkaitan dengan persetujuan proses transaksi yang berlaku itulah yang berlaku meskipun dalam proses tersebut masih ada kemungkinan customer memberikan data yang tidak benar, sedangkan penjual melalui perangkat software yang digunakan telah menyetujui transaksi tersebut, sehingga suatu kesepakatan kehendak antar para pihak telah terjadi ketika customer melakukan pengisian order form, dan penjual dengan menggunakan perangkat software menyetujuitransaksi tersebut.

\section{Teori Konfirmasi}

Teori ini menjelaskan bahwa suatu kata sepakat telah ada atau dianggap telah terjadi ketika pihak yang melakukan penawaran mendapat jawaban atau konfirmasi jawaban dari pihak yang menerima tawaran, sehingga kata sepakat dalam transaksi e-commerce terjadi ketika penjual mendapat jawaban dari customer atas berita konfirmasi jawaban dari pihak yang melakukan penawaran termasuk juga informasi yang dikirimkan oleh customer yang telah memenuhi persyaratan atau dinyatakan valid.

\section{Pengaturan hukum terhadap transaksi elektronik berdasarkan Undang-}




\section{Undang Nomor 11 Tahun 2008 tentang Informasi dan Transaksi Elektronik}

Disahkannya Undang-Undang Nomor 11 Tahun 2008 tentang Informasi dan Transaksi Elektronik (ITE) pada bulan April 2008 menjawab kebutuhan akan adanya kepastian hukum dalam bidangtransaksi elektronik. Undang-UndangInformasi dan Transaksi Elektronik (UU ITE) mengatur berbagai perlindungan hukum atas kegiatan yang memanfaatkan internet sebagai medianya, baik transaksi maupun pemanfaatan informasinya. Pada Undang-Undang Informasi dan Transaksi Elektronik ini juga diatur berbagai ancaman hukum bagi kejahatan melalui internet. Undang- Undang Informasi dan Transaksi Elektronik mengakomodir kebutuhan para pelaku bisnis di internet dan masyarakat pada umumnya guna mendapatkan kepastian hukum, dengan diakuinya bukti elektronik dan tanda tangan digital sebagai bukti yang sah di pengadilan.

"Perkembangan teknologi informasi di Indonesia sangat pesat terbukti dengan data statistik yang dikeluarkan oleh Asosiasi Pengusaha Jasa Internet Indonesia (APJII). Pengguna internet mencapai 25 juta orang." ${ }^{.7}$ Dengan sendirinya penguna transaksi elektronik juga meningkat. Melalui transaksi elektronik yang lintas batas, Indonesia tidak bisa lagi menganggap masalah privasi atas informasi pribadi dengan sebelahmata karena sudah menjadi masalah internasional. Indonesia harus dapat menyesuaikan dengan cara melakukan harmonisasi hukum yang khususnya yang berkaitan dengan pengaturan privasi atas informasipribadi disamping itu dengan lahirnya konsep e-government dan transaksi elektronik maka akan mendorong pemerintah untuk melindungi privasi khususnya atas data atau informasi pribadi masyarakat.

Pengaturan mengenai Transaksi Elektronik terdapat di dalam Pasal 17 sampai dengan Pasal 22, penyelenggaraan Transaksi Elektronik dapat dilakukan dalam lingkup publik ataupun privat, dan bagi para pihak yang melakukan Transaksi Elektronik wajib beritikad baik dalam melakukan intraksi ataupun pertukaran Informasi Elektronik selama transaksiberlangsung didalam Pasal 17 ayat (5) ini menjelaskan bahwa Transaksi

Elektronik dapat dilakukan dalam lingkup publik ataupun privat, tetapi kenyataannya Transaksi Elektronik yang banyak dilakukan ialah dalam lingkup privat. Karena Transaksi Elektronik yang dituangkan kedalamkontrak Elektronik mengikat para pihak.

\section{Keabsahan kesepakatan melalui transaksi elektronikberdasarkan Undang-UndangNomor}

\section{Tahun 2008 tentang Informasi dan Transaksi Elektronik}

Undang-Undang Nomor 11 Tahun 2008 Tentang Informasi dan Transaksi Elektronik selanjutnya disebut UU ITE, memberikanpengakuan Kontrak Elektronik ini pada Pasal 1 angka 17 UU ITE dengan perjanjian para pihak yang dibuat melalui sistem elektronik, selanjutnya Pasal 1 angka 5 UU ITE mengenai sistem elektronik disebutkan serangkaian perangkat dan prosedur elektronik yang berfungsi mempersiapkan, mengumpulkan, mengolah, menganalisis, menyimpan, menampilkan, mengumumkan, mengirimkan, dan/atau menyebarkan Informasi Elektronik.

Pada hakekatnya kontrak elektronik adalah perjanjian yangdisepakati para pihak yang membuatnya hanya sarananya sangat berbeda menggunakan sistem elektronik. Keabsahan suatu kontrak elektronik ini dijelaskan pada UUITE dalam Pasal 5 ayat (3) UU ITE dengan mensyaratkan keabsahan kontrak (dokumen elektronik) bila menggunakan Sistem Elektronik yang sebagaimana diatur dalam Pasal 13 sampai dengan Pasal 16 UU ITE mengenai persyaratan penggunaan sarana sistem elektronik yang sudah disertifikasi.esepakatan yang dilakukan melalui surat elektronik (E-Mail), selanjutnya disebut kontrakelektronik adalah sebuah bentuk perjanjian dibawah tangan yang dibuat oleh para pihak dengan menggunakan sistem elektronik sebagai medianya. Kontrak Elektronik merupakan perwujudan bentuk dari Pasal 1338 K.U.H. Perdata yang memberlakukan "Asas Kebebasan Berkontrak". Sehingga mengenai keabsahan kontrakelektronik ditinjau dari K.U.H. Perdata, maka harus dilihat secara jelas apakah sudah sesuai dengan Pasal 1320 K.U.H. Perdata mengenai syarat sah perjanjian.

Tidak secara khusus diatur di,dalam KUHPerdata mengenaikeabsahan kesepakatan yang dilakukan melalui e-mail, namunberdasarkan Pasal 1320 angka (1) K.U.H. Perdata, yang berbunyi "sepakat mereka yang mengikatkan dirinya". Dapat disimpulkan bahwa maksud dari kata sepakat adalah, kedua belah pihak yang membuatperjanjian setuju mengenai hal-hal yang pokok dalam kontrak. Kesepakatan berarti ada persesuaian kehendak yang bebas antara para pihak mengenai hal-hal pokok yang diinginkan dalam perjanjian. Dalam hal ini, antara para pihak harus mempunyai kemauan yang bebas (suka rela) untuk mengikatkan diri, di mana kesepakatan itu dapat dinyatakan secara tegas maupun diam-diam. Bebas di sini artinya adalah bebas dari kekhilafan (dwaling, mistake), paksaan (dwang, dures), dan penipuan (bedrog, fraud). Secara 
a contrario, berdasarkan Pasal 1321 K.U.H. Perdata, perjanjian menjadi tidak sah, apabila kesepakatan terjadi karena adanya unsur-unsur kekhilafan, paksaan, atau penipuan. Dengan demikian selama tidak melanggar ketentuan yang terdapat pada Pasal 1320 dan Pasal 1321 K.U.H. Perdata maka kesepakatan yang dilakukan melalui e-mail dianggap sah.Selanjutnya melalui teori offer and acceptance, dilihat dari cara terjadinya kesepakatan maka dapat dikatakan sah karena dilakukan secara tertulis, meskipun tidak lagi secara konvensional (tinta diatas kertas).

6. Keabsahan penggunaan tanda tangan digital (digital signatur) pada kesepakatan yang dilakukan melalui surat elektronik berdasarkan Undang- Undang Nomor 11 Tahun 2008 tentang Informasi dan Transaksi Elektronik

Pengaturan penandatanganan non elektronik ditegaskan dalam Pasal 1 Ordonansi Tahun 1867 Nomor 29, menyatakan bahwa ketentuan tentang kekuatan pembuktian dari tulisan- tulisan di bawah tangan dari orang- orang Indonesia atau yang disamakan dengan mereka. Sejalan dengan itu Yahya Harahap juga menguraikan arti penting tanda tangan. Menurut kepustakaan tersebut, tanda tanganberfungsi sebagai syarat yang mutlak sahnya suatu akta.

\section{Dari uraian di atas dapat}

disimpulkan hakikat dari pada tanda tangan digital sebagai berikut : pertama, sebagai alat bukti identifikasi para pihak. Dari mekanisme atau tata kerja lahirnya tanda tangan digital melalui proses enkripsi dengan teknik kriptografi, lahirlah kunci privat dari salah satu pihak sehingga dapat membuka kunci pulik milik pelanggan dari salah satu pihak yang hendak melakukan perjanjian tersebut. Kedua, memenuhi syarat formalitas. Dilibatkannya lembaga certification authority sebagai lembaga yang dipercaya untuk menjamin kerahasiaan digital signature. Negara

masih mengusahakan agar memilki lembaga yang berada di bawah naungan Pemerintah untuk menerbitkan sertifikat digital. Ketiga, tanda persetujuan. Sifat yang ada dalamtanda tangan digital sebagai kunci untuk membuka kontrak yang telah dienkripsi pula maka pada saat pihak yang memiliki kunci privat mencocokan kunci publik milik pelaku usaha misalnya, maka pada saat pihak yang memiliki kunci publik itu mengetahui penawaran pelanggannya, maka saat itu juga merupakan tanda persetujuan atas peristiwa hukum yang akan terjadi dari kedua pihak. Keempat, efisiensi. Setelah pelanggan menyatakan persetujuannya dengan membuka atau melakukan dekripsi atas kontrak yang telah dienkripsi, dan membaca segala ketentuan yang harus diikuti terhadap pelaku usaha, maka kedua pihak secara tegas menyepakati tunduk pada ketentuan yang ada dalam kontrak yang telah dienkripsi itu. Dalam kaitan dengan uraian di atas, sertifikat digital yang kemudian melahirkan dokumen atau surat elektronik hanyalah dapat digolongkan dalam akta bawah tangan. Sertifikat digital dengan prinsip kerjanya menjamin rahasia dari surat tersebut oleh para pihak yang melakukan transaksi elektronik. Tapi satu sifat yang dimiliki oleh akta otentik tidak berlaku dalam sertifikat digital. "Sifat yang melekat dalam akta otentik adalah akta yang dibuat oleh pejabat yang berwenang."

Pasal 5 ayat (1) sampai dengan ayat (3) UU ITE, secara tegas menyebutkan bahwa informasi elektronik dan/atau dokumen elektronik dan/atau hasil cetaknya merupakan alat bukti hukum yang sah dan merupakan perluasan dari alat bukti yang sah sesuai dengan hukum acara yang berlaku di Indonesia sesuai dengan ketentuan yang diatur dalam undangundang. Namun, dalam ayat (4) ada pengecualian yang menyebutkan informasi elektronik dan/atau dokumen elektronik tidak berlaku untuk : (a) surat yang menurut undang-undang harus dibuat dalam bentuk tertulis; dan (b) surat beserta dokumennya yang menurutundang-undang harus dibuat dalambentuk akta notaril atau akta yang dibuat oleh pejabat pembuat akta.

\section{Upaya hukum terhadap wanprestasi dalam transaksi elektronik berdasarkan Undang- Undang Nomor 11 Tahun 2008 tentang Informasi dan Transaksi Elektronik}

Munir Fuady mengartikan wanprestasi (default atau non fulfillment) ataupun yang disebutjuga dengan istilah (breach of contract) yang dimaksudkan adalah tidak dilaksanakan prestasiatau kewajiban sebagaimana mestinya yang dibebankan oleh kontrak terhadap pihak-pihak tertentu seperti yang disebutkan dalam kontrak yang bersangkutan". Pengertian serupa tentang wanprestasi diungkapkan oleh. "Salim H.S disebutkan wanprestasi adalah tidak memenuhi atau lalai melaksanakan kewajibansebagaimana yang ditentukan dalam perjanjian yang dibuat antara kreditur dengan debitur." 10 Tidak dapat dipenuhinya kewajiban dalam perjanjian dapat disebabkan berikut: ${ }^{11}$

1) Karena kesalahan debitur (baik karena kesengajaan maupunkelalaian); 
2) Karena keadaan memaksa (force major) Wanprestasi dalam suatu perjanjian wujudnya dapat berupa:

a) Debitur sama sekali tidak memenuhi perjanjian; Debiturtidak memenuhi kewajiban yang telah disanggupinya untuk dipenuhi dalam suatu perjanjian atau tidak memenuhi kewajiban yang ditetapkan oleh undang- undang;

b) Debitur terlambat memenuhi perjanjian; Debitur memenuhiprestasi tetapi tidak tepat waktu, waktu yang ditetapkan dalam perjanjian tidak dipenuhi;

c) Debitur keliru memenuhi prestasi; Debitur melaksanakan atau memenuhi apa yang diperjanjikan atau apa yang ditentukan oleh undang-undang tetapi tidak sebagaimana mestinya menurut kualitas yang telah ditentukan dalamperjanjian atau yang telah ditetapkan oleh undang-undang;

d) Debitur melakukan sesuatu yang menurut perjanjian atau tidak boleh dilakukan.

Adapun akibat hukum bagi debitur yang telah melakukan wanprestasi adalah hukuman atau sanksi sebagi berikut: ${ }^{12}$

1) Debitur diharuskan membayar ganti kerugian yang telah diderita oleh kreditur (Pasal 1243 K.U.H. Perdata). Ketentuan ini berlaku untuk semua perikatan;

2) Dalam perjanjian timbal balik, wanprestasi dari satu pihak memberikan hak kepada pihak yang lain untuk membatalkan atau memutuskan perjanjian lewat hakim (Pasal 1266 K.U.H.Perdata);

3) Risiko beralih kepada debitur sejak terjadinya wanprestasi (Pasal 1237 ayat

K.U.H. Perdata). Ketentuan ini hanya berlaku bagi perikatan untuk memberikan sesuatu;

4) Membayar biaya perkara apabila diperkarakan dimuka hakim. Ketentuan ini untuk semua perikatan;

5) Memenuhi perjanjian jika masih dapat dilakukan, atau pembatalan perjanjian yang disertai dengan pembayaran ganti rugi (Pasal 1267

K.U.H. Perdata). Ketentuan ini berlaku untuk semua perikatan.

\section{8. $\quad$ Penyelesaian sengketa dalamtransaksi elektronik berdasarkan Undang-}

\section{Undang Nomor 11 Tahun 2008 tentang Informasi dan Transaksi Elektronik}

Salah satu unsur wanprestasi adalah berakibat merugikan orang lain. Hal ini sesuai dengan yang dikemukakan oleh Yahya Harahap sebagai berikut: "Jika wanprestasi itu benarbenar menimbulkan kerugian kepada kreditur, maka debitur wajib mengganti kerugian yang timbul. Namun untuk itu harus ada hubungan sebab akibat atau kausal verband kerugian." Dengan demikian seseorang yang wanprestasi memberikan hak kepada pihak lain yang dirugikannya untuk menggugat ganti kerugian. Mengenai bentuk ganti kerugian, Pasal 1246 K.U.H. Perdata menentukan bahwa biaya, rugi dan bunga yang oleh si berpiutang boleh dituntut akan penggantiannya, terdirilah pada umumnya atas rugi yang telah dideritanya dan untung yang sedianya harus dapat dinikmatinya."

Gugatan ganti kerugian atas dasar perbuatan melanggar hukum, diawali pada mulanya perbuatan melawan hukum hanya ditujukan pada perbuatan yang bertentangan dengan peraturan perundang-undangan yang berlaku saja. Namun setelah tahun 1919, yang dipelopori oleh Pengadilan Tertinggi di Negeri Belanda (Putusan Hoge Raad) tanggal 31 Januari 1919. Istilah "onrechtmatige daad" ditafsirkan secara luas, sehingga meliputi pula suatu perbuatan yang bertentangan dengan kesusilaan atau dengan yang dianggap pantas dalam pergaulan hidup masyarakat. Berdasarkan Arrest Hoge Raad 1919, suatu perbuatan melawan hukum, jika:

a. melanggar hak orang lain;

b. bertentangan dengan kewajiban hukum dari si pelaku;

c. bertentangan dengan kesusilaan; dan

d. bertentangan dengan kepatutan yang berlaku dalam lalu-lintas masyarakat terhadap diri atau barang orang lain.

Gugatan ganti rugi atas dasar perbuatan melanggar hukum diatur dalam Pasal 1365 K.U.H Perdata, yang menentukan: "Tiap perbuatan melanggar hukum, yang membawa kerugian kepada seorang lain, mewajibkan orang yang karena salahnya menerbitkan kerugian itu,menggantikan kerugian tersebut". Pasal 1365 K.U.H. Perdata tersebut, di dalamnya terkandung unsur-unsur:

a. Perbuatan yang melanggar hukum (onrechtmatige daad);

b. Harus ada kesalahan; 
c. Harus ada kerugian yang ditimbulkan; dan

d. Adanya hubungan kausal antara perbuatan dan kerugian ${ }^{14}$.

\section{Penerapan dan mekanisme penyelesaian sengketa alternatif dalam sengketa transaksielektronik}

Undang-Undang Nomor 30 Tahun 1999 tentang Arbitrase dan Alternatif Penyelesaian Sengketa memberikan kemungkinan dipergunakannya e-mail dalam proses penyelesaian sengketa, sekalipun baru dalam tahap penyampaian surat. "Dalam haldisepakati penyelesaian sengketa melalui arbitrase terjadi dalam bentuk pertukaran surat, maka pengirimantelegram, faksimil, e-mail atau dalam bentuk sarana komunukasi lainnya, wajib disertai dengan suatu catatan penerimaan oleh para pihak." Mediasi dalam sengketa transaksi elektronik, menjadi salah satu bentuk penyelesaian yang dipilih oleh para pihak yang bersengketa. Melalui pihak ketiga yang netral akan duduk bersama-sama dengan para pihak yang bersengketa dan secara aktifakan membantu para pihak dalamupaya menemukan kesepakatan yang adil dan memuaskan bagi keduanya. Dalam proses mediasi, seorang mediator hanya berperan sebagai fasilitator saja.

Oleh karena itu, mediator tidak mempunyai kewenangan untuk membuat suatu keputusan yang mengikat para pihak. Seorang mediator akan membantu para pihakyang bersengketa untuk mengidentifikasi persoalan-persoalan yang menjadi pokok sengketa, memfasilitasi komunikasi di antara kedua belah pihak, serta berupaya menemukan informasi tentang apa yang sesungguhnya terjadi dan apa yang menjadi kepentingan dan keinginan masing-masing pihak yang bersengketa. Informasi ini biasanya dapat diketahui pada saat mediator melakukan intrerview secara pribadi (private session) dengan masing- masing pihak.

\section{KESIMPULAN}

Dari pembahasan diatas dapat disimpulkan bahwa Keabsahankesepakatan yang dilakukan melalui surat elektronik (e-mail) di Indonesia tidak secara khusus diatur di dalam Kitab Undang-Undang Hukum Perdata, namun dalam Pasal 47 ayat (2) huruf a Peraturan Pemerintah Republik Indonesia Nomor 82 Tahun 2012 Tentang PenyelenggaraanSistem Dan Transaksi Elektronikpada, kesepakatan merupakan salah satu syarat sahnya sebuah perjanjian. Jika dikaji menggunakan teori offer and acceptance, maka kesepakatan yang menggunakan surat elektronik sebagai medianya dapat dikatakan sah, dilihat dari cara terjadinya dilakukan secara tertulis, meskipun tidak lagi secara konvensional (tinta diatas kertas).
Dalam transaksi elektronik kesepakatan tidak diberikan secara langsung melainkan melalui media elektronik seperti jaringan internet, baik lewat $e$-mail atau form pemesanan. Oleh karena itu, perlu ditentukan kapan kesepakatan dalam transaksi elektronik tercapai. UU ITE pada dasarnya diberikan kebebasan kepada para pihak untuk menentukan kapan kesepakatan dicapai, jika para pihak tidak menentukan kapan kesepakatan dicapai, UU ITEmengatur bahwa kesepakatan terjadi pada saat penerima/pembeli menerima dan menyetujui penawaran yang disampaikan oleh

pengirim/penjual, hal ini dimaksudkan untuk memberikansimplikasi mengingat dalam transaksi bisnis orang menginginkan adanya kepraktisan sekaligus kepastian hukum.

\section{DAFTAR PUSTAKA}

Cita Yustisia Serfiani dkk., Buku Pintar Bisnis Online dan Transaksi Elektronik, Gramedia Pustaka Utama, Jakarta, 2013.

Harahap, M. Yahya, Segi-segi Hukum Perjanjian, Alumni, Bandung, 1986.

Munir, Fuady, Pengantar Hukum Bisnis: Menata Bisnis Modern Di Era Global, PT.Citra Aditya Bakti, Bandung, 2005.

Muhammad, Abdulkadir, Hukum Perikatan, Citra Aditya Bakti, Bandung, 2003.

Marzuki, Peter Mahmud, Penelitian Hukum, Cet. 6, Kencana Prenada Media Group, Jakarta, 2010.

Purwaningsih, Endang, Hukum Bisnis, Ghalia Indonesia, Bogor, 2010

Remy Sjahdeny Sultan, Kebebasan Berkontrak dan Perlindungan Yang Seimbang Bagi Para Pihak Dalam Perjanjian Kredit Bank Di Indonesia, Institut Bankir Indonesia, Jakarta, 1993

Suharnoko, Hukum Perjanjian (Teori dan Analisa Kasus), Prenada Media, Jakarta, 2004

Salim H.S, Hukum Kontrak, Sinar Grafika, Jakarta, 2003

Patuju La, Keadilan, "Kemanfaatan, danKepastian Hukum Serta Hubungan Diantara Ketiganya".Diunggah tanggal 11, Maret 2021, 